\title{
Retrospective Observational Study to Detect the Etiological Spectrum and the Sensitivity Pattern of Organisms Isolated From Septic Ward Patients at Tertiary Care Centre
}

\author{
E. Padmavathi, A. Gowri Sankar, Gowri Veligandla* and M. Bhaskar \\ Department of Microbiology, Government Vellore Medical College, Vellore, Tamilnadu, India \\ *Corresponding author
}

\begin{tabular}{|c|c|}
\hline & A B S T R A C T \\
\hline & $\begin{array}{l}\text { Wound infection is an important cause of morbidity and mortality of patients irrespective } \\
\text { of the cause of the wound. Septic ward is a place where lot of wound infections are seen. } \\
\text { Wound infections are significant as most common cause of hospital acquired infections. In }\end{array}$ \\
\hline Keywords & $\begin{array}{l}\text { a developing and resource poor country like ours, wound infections often increase the } \\
\text { duration of the hospital stay of the patients. With inadequate diagnostic facilities and lack }\end{array}$ \\
\hline $\begin{array}{l}\text { Organisms, } \\
\text { Etiological } \\
\text { spectrum, } \\
\text { Sensitivity } \\
\text { pattern, } \\
\text { E. coli }\end{array}$ & $\begin{array}{l}\text { of knowledge about the local epidemiological data on the prevalent causative organisms } \\
\text { and sensitivity patterns of wound infections, a great dilemma is faced by the treating } \\
\text { doctor. With this background the present study was designed to detect the spectrum of the } \\
\text { infectious agents, their sensitivity patterns among the patients admitted with wound } \\
\text { infection in the septic ward of our tertiary care centre. This observational study was } \\
\text { conducted to analyze the culture and sensitivity reports of pus samples and wound swabs } \\
\text { received from patients admitted to the surgical septic ward and sent to the Diagnostic }\end{array}$ \\
\hline Article Info & $\begin{array}{l}\text { Microbiology lab for processing. These were collected restrospectively from the records } \\
\text { maintained in the Denartment of Microbiology over a period of six months from October }\end{array}$ \\
\hline $\begin{array}{l}\text { Accepted: } \\
\text { 04 May } 2017 \\
\text { Available Online: } \\
\text { 10 June } 2017\end{array}$ & $\begin{array}{l}2016 \text { to March } 2017 \text { in our hospital. Data were analyzed statistically. During the study } \\
\text { period, } 107 \text { pus and wound culture sensitivity reports were analyzed. Klebsiella }(31.8 \%) \\
\text { was the most common organism isolated followed by Proteus }(18.6 \%) \text { and E. coli }(15.3 \%) \text {. } \\
\text { The isolates were sensitive to gentamycin, ciprofloxacin, meropenem - piperacillin and }\end{array}$ \\
\hline & $\begin{array}{l}\text { tazobactum - amikacin. However, high resistance rates were observed for ampicillin and } \\
\text { cefotaxime in our study. The present study provided a baseline data of wound infections } \\
\text { prevalent in our geographical area, the common etiological organisms and their sensitivity } \\
\text { patterns. This study also highlights the emerging drug resistance and the need for rational } \\
\text { use of antibiotics. }\end{array}$ \\
\hline
\end{tabular}

\section{Introduction}

The loss of continuity of epithelium, with or without loss of underlying connective tissue will lead to a breakdown in the protective function of the skin, this is called a wound as defined by Leaper DJ et al., (1998). An infection of this breach in continuity constitutes wound infection. These can be accidental, pathological or post-operative. Wound infection often manifest with presence of pus associated with general or local features of sepsis such as pyrexia, pain and induration. Wound infections are also significant in that they are the most common nosocomial infection as stated by Diogini et 
al., (2001). It is also important because it can delay healing and cause wound breakdown. This is also associated with longer hospital stay and increased cost of healthcare as mentioned by Sule et al., (2002). Studies on wound infection by Sands et al., (1996), Garner et al., (1985), Gaynes et al., (2001) have largely focused on surgical site infections. This might be because other types of wound infection are not problematic in the developed world where most of these studies have been done. However various studies in developing and resource-poor countries, by Mehta et al., (2007), Karia et al., (2013), Anguzu et al., (2007) suggest that other types of wound infection in addition to surgical site infection are still important causes of morbidity and mortality. Where studies have been done on wound infections generally, regional and local variations have been observed in terms of the causative microorganisms as stated by Rao et al., (2014), Sule et al., (2002) and Egbe et al., (2011). This means that physicians need to know the prevalent organisms and the resistance patterns existing in their localities.

With this background an observational retrospective study was planned to establish baseline indices of wound infection in our geographical area, to detect the locally prevalent micro-organisms involved in wound infections and their drug resistance patterns.

\section{Materials and Methods}

This is a retrospective cross-sectional study planned after obtaining institutional ethical committee clearance, in a span of 6 months from October 2016 to March 2017. The records from the Department of Microbiology, of pus and wound swab samples obtained from patients with different kinds of wounds admitted to surgical septic ward of our tertiary care centre, Government Vellore Medical College, Vellore were analysed.

\section{Exclusion / inclusion criteria}

The records were scrutinised to include all patients of age group more than 20 years with suspected wound infections admitted to the septic ward. Wound infection was suspected if a wound was not healing well, getting bigger, exuding pus or fluid. Very ill patients and those undergoing antibiotic therapy two weeks prior to the study were excluded. Patients' age, sex and type of wound were noted.

The details of the specimens collected, transported, processed according to standard procedures and the significant pathogens isolated were noted down. The antibiotic susceptibility patterns of the significant isolates which were tested and interpreted according to CLSI guidelines as documented in the records of the diagnostic microbiology laboratory at our tertiary care centre, were noted and analyzed.

\section{Results and Discussion}

A total of 107 pus and wound swab samples received at the Microbiology Department, Government Vellore Medical College during the study period were analyzed. Among the samples tested 4(3.7\%) were reported to be contaminated. No growth was reported in $12(11.2 \%)$ samples. There were 89 single causative organisms isolated and 2 polymicrobial isolates. There were 63 male subjects and 3 female subjects, the male: female ratio being 2.1:1. Ages ranged from 21 years to 85 years.

Table 1 shows the age distribution of patients with wound infections and the number of organisms isolated. The maximum number of patients admitted with wound infections was highest in the age group 51 to 60 years followed by 61-70 years showing that the increase in the incidence of wound infection 
was more with increasing age. This may be attributed to many contributing factors such as the presence of co- morbidities like diabetes, socio-economic status, nutrition etc. This is evident from our study which shows the wound infections are common in the age group of 50 years and above. This is consistent with the results of a study done by Egby et al., (2011) in the Niger Delta region and another study by Mulugeta et al., (2011). However, in another study by Kemebradikumo et al., (2013) conducted in Nigeria there was no association between age and wound infection.

Table 2 shows the distribution of the etiological agents in wound infections. A total of 89 samples $(83.1 \%)$, yielded significant bacterial growth of 91 isolates indicative of wound infection. Our study demonstrated a high prevalence $(83.1 \%)$ of pathogenic bacteria in wounds. This high figure is consistent with that obtained in similar studies in Rao et al., (2014), Shittu et al., (2002), Taiwo et al., (2002)., Kemebradikumo et al., (2013) but different from another study by Mulugeta et al., (2011) that reported a prevalence of $70.5 \%$.

Gram negative bacilli were the most prevalent bacteria isolated from pus and the wound swabs (81.3\%). Klebsiella species (31.8\%) was the most prevalent pathogen detected followed by Proteus species (18.6\%) and Escherichia coli $(15.3 \%)$ respectively. There were similar studies that reported Gram negative bacilli as the most prevalent pathogen in wound such as in Rameshkannan et al., (2014). In the present study Klebsiella species was the commonest organism as was observed in Sule et al., (2002), and unlike other studies that reported E. coli like Rameshkannan et al., (2014), and Pseudomonas aeruginosa as in Kemebradikumo et al., (2013). Among the gram positive organism's isolated Coagulase negative Staphylococcus species constituted (14.2\%), followed by Staphylococcus aureus $(4.3 \%)$. This was in contrast to another study by Karia et al., (2013), that had reported Staphylococcus aureus as the single most common pathogen isolated from wound infections.

The bacterial isolates exhibited a high resistance to the antibiotics tested. Most of the organisms isolated were resistant to ampicillin.

Among the Klebsiella isolated from the specimens in this study, most of the isolates were sensitive to Gentamycin (70.8\%), 87.5\% strains were resistant to Ampicillin and $62.5 \%$ strains were resistant to Ciprofloxacin. $4.1 \%$ strains were resistant to PiperacillinTazobactum and $8.3 \%$ strains showed resistance to Meropenem. This sensitivity pattern shows gradually increasing resistance to second line drugs like Meropenem, Piperacillin-Tazobactum and is alarming and invites concern.

Table.1 Age distribution of the patients with wound infections and

The number of organisms isolated

\begin{tabular}{|l|l|l|}
\hline S. No. & Age in years & No. of isolates \\
\hline 1 & $21-30$ & 1 \\
\hline 2 & $31-40$ & 2 \\
\hline 3 & $41-50$ & 19 \\
\hline 4 & $51-60$ & 36 \\
\hline 5 & $61-70$ & 2 \\
\hline 6 & $>70$ yrs & 10 \\
\hline
\end{tabular}


Table.2 Etiological agents isolated from wound infections

\begin{tabular}{|l|l|l|}
\hline S. No. & Etiological agent & Number isolated (\%) \\
\hline 1 & Klebsiella $\mathrm{sp}$ & $29(31.8 \%)$ \\
\hline 2 & Proteus $\mathrm{sp}$ & $17(18.6 \%)$ \\
\hline 3 & E. coli $\mathrm{sp}$ & $14(15.3 \%)$ \\
\hline 4 & CONS & $13(14.2 \%)$ \\
\hline 5 & Pseudomonas $\mathrm{sp}$ & $8(8.7 \%)$ \\
\hline 6 & Enterococci $\mathrm{sp}$ & $1(1 \%)$ \\
\hline 7 & Enterobacter $\mathrm{sp}$ & $3(3.2 \%)$ \\
\hline 8 & Staphylococcus aureus & $4(4.3 \%)$ \\
\hline 9 & Acinetobacter & $2(2.1 \%)$ \\
\hline
\end{tabular}

Among the Proteus species $47.3 \%$ were sensitive to Ciprofloxacin and $76.4 \%$ were resistant to Ampicillin. In this study the development of resistance to cephalosporins (50\%) was observed among the E. coli isolates.

No significant difference in resistance was observed with regard to age, sex or type of wound. Most of these studies, including ours, are limited by the fact that anaerobic cultures were not done for a variety of reasons, the main one being a lack of equipment and funds. Thus, anaerobic bacteria, which are also important in wound infections, could not be isolated.

A study by Hart et al., (1998), have mentioned that the lack of diagnostic facilities in these developing regions encourages empiric treatment and over treatment which contribute to the increased resistance to antibiotics.

This study is thus an eye-opener demanding an antimicrobial policy for each geographical region. It also invites attention to initiate steps to prevent antimicrobial resistance. The poor availability of antibiotics, as well as their unregulated use and misuse, has been shown to contribute to increasing antimicrobial resistance in developing countries as stated by Hart et al., (1998).
In conclusion, multiple antibiotic resistances in bacterial population are a great challenge in the effective management of wound infections. This study highlights the need to monitor and optimize the use of already limited array of antimicrobial agents.

A multidisciplinary approach to wound infection management involving both clinicians and microbiologists will definitely help to put a check on the slowly rising antimicrobial resistance. Strengthened laboratory services at local and national levels, effective surveillance of antimicrobial resistance and stringent antibiotic policies formulated after identifying the etiological spectrum of locally prevalent pathogens will help us combat this alarming drug resistance patterns.

This study also emphasizes the need for further studies in this area involving larger study population and correlation with other local contributing factors.

\section{References}

Alexander FM et al., 1994. Wound Infection: Nursing Practice Hospital and Home, the Adult. New York: Churchill Livingstone; 1994

Anguzu JRet al., 2007. Drug sensitivity patterns of bacterial isolates from septic post-operative 
Wounds in a regional referral hospital in Uganda. Afr Health Sci 2007; 7(3): 148- 154.

Dionigi R et al., 2001. Risk factors in surgery. J Chemother 2001; Spec No 1(1): 6- 11

Egbe C et al., 2011. Microbiology of Wound Infections Among patients of a Tertiary Hospital in Benin City, Nigeria. J Res Health Sci 2011; 11(2): 109-113.

Fadeyi A et al., 2008. Adigun I, Rahman G. Bacteriological pattern of wound swab isolates in Patients with chronic leg ulcer. Int J Health Res 2008; 1(4): 183-188.

Garner JS et al., 1995. CDC guideline for prevention of surgical wound infections, 1985. Supersedes guideline for prevention of surgical wound infections published in 1982. Infect Control1986; 7(3): 193-200.

Gaynes R et al., 2001. J. Surgical Site Infection (SSI) Rates in the United States, 1992-1998: The National Nosocomial Infections Surveillance System Basic SSI Risk Index. Clin Infect Dis 2001; 33(Suppl 2): S69-S77.

Hart C et al., 1998. Antimicrobial resistance in developing countries. BMJ 1998; 317: 647650.

Karia JB et al., 2013. Study of bacterial profile of pus culture in dhiraj General hospital. Indian $\mathbf{J}$ Surg Oncol. 2013; 4(2):172-218.

Kemebradikumo Pondei et al., 2013. Current Microbial Isolates from Wound Swabs, Their Culture and Sensitivity Pattern at the Niger Delta University Teaching Hospital, Okolobiri, Nigeria.Trop Med Health 2013 Jun; 41(2):49-53.

Leaper DJ et al., 1998. Wounds: Biology and Management. Oxford, England: Oxford University Press; 1998
Mehta M et al., 2007. Bacterial isolates from burn wound infections and their antibiograms: A eight-year study. Indian J Plastic Surg 2007; 40(1): 25-28

Mulugeta KA et al., 2011. Bayeh A. Bacteriology and antibiogram of pathogens from wound Infections at Dessie Laboratory, North East Ethiopia. Tanz J Health Res 2011; 13(4).

Rameshkannan S et al., 2014, Indian Journal of Basic and Applied Medical Research; December 2014: Vol.-4, Issue- 1, P. 243-248.

Rao R et al., 2014. Aerobic Bacterial Profile and Antimicrobial Susceptibility Pattern Of Pus Isolates in a South Indian Tertiary Care Hospital. IOSR-JDMS. 2014; 13(3):59-62.

Sands K et al., 1996. Surgical site infections occurring after hospital discharge. J Infect Dis 1996; 173: 963-970.

Shittu A et al., 2002. A study of wound infections in two health institutions in Ile-Ife, Nigeria.African J Biomed Res 2002; 5: 97102.

Sule A et al., 2002. Bacterial pathogens associated with infected wounds in Ogun State University Teaching Hospital, Sagamu, Nigeria. Afr J Clin Exp Microbiol 2002; 3(1): $13-16$

Taiwo S et al., 2002. Invitro antimicrobial susceptibility pattern of bacterial isolates From wound infections in University of Ilorin Teaching Hospital. Afr J Clin Exp Microbiol 2002; 3(1): 6-10.

Wariso B et al., 2003. A survey of common pathogens in wounds in patients at the University of Port Harcourt Teaching Hospital (U.P.T.H), Port Harcourt. West Afr J Med 2003; 22(1): 50-54.

\section{How to cite this article:}

Padmavathi E., Gowri Sankar A., Gowri Veligandla and Bhaskar M.. 2017. Retrospective Observational Study to Detect the Etiological Spectrum and the Sensitivity Pattern of Organisms Isolated From Septic Ward Patients at Our Tertiary Care Centre. Int.J.Curr.Microbiol.App.Sci. 6(6): 521-525. doi: https://doi.org/10.20546/ijcmas.2017.606.061 